Article

\title{
Delivering Smart Governance in a Future City: The Case of Glasgow
}

\author{
Charles Leleux * and William Webster
}

Centre for Research into Information, Surveillance and Privacy, Stirling Management School, University of Stirling, Stirling, FK9 4LA, UK; E-Mails: charles.leleux@stir.ac.uk (C.L.), william.webster@stir.ac.uk (W.W.)

* Corresponding author

Submitted: 20 June 2018 | Accepted: 4 September 2018 | Published: 21 December 2018

\begin{abstract}
In 2013, Glasgow City Council received significant funding to develop innovative smart city applications, including the delivery of new electronic public services and the co-production of governance. This case study examines the processes that underpin the ways in which the 'Future City Glasgow programme' delivered 'smart governance', in the context of a regenerating post-industrial city. We assess the contribution of smart city technologies and data collection and monitoring processes designed to facilitate citizen engagement and sustainable governance practices. The Future City Glasgow programme ran from 2013-2015, and included the Open Glasgow project, and 'Demonstrator Projects' of: Energy Efficiency; Intelligent Street Lighting; Active Travel; and, Integrated Social Transport. Opportunities arose from these demonstrators for developing co-production and legacy initiatives. The case study provides insight into the ways in which citizens and local communities in Glasgow have been engaged in governance processes. This engagement has taken place via traditional and innovative smart city technologies, and in particular in relation to policy formulation, service design and delivery. It finds that the co-creation of governance is shaped by vested interests, that engagement is fragmented and partial, but at the same time new technologies, social media and shared learning opportunities offer innovative new ways for some citizens to influence local governance.
\end{abstract}

\section{Keywords}

citizen engagement; co-production; eGovernment; Future City Glasgow; Glasgow; post-industrial city; smart governance; sustainability

Issue

This article is part of the issue "E-Government and Smart Cities: Theoretical Reflections and Case Studies", edited by Peter Mechant (Ghent University, Belgium) and Nils Walravens (Vrije Universiteit Brussel, Belgium).

(C) 2018 by the authors; licensee Cogitatio (Lisbon, Portugal). This article is licensed under a Creative Commons Attribution 4.0 International License (CC BY).

\section{Introduction}

The city of Glasgow, population 615,000 (Glasgow City Council [GCC], 2018a), is the largest of the seven cities in Scotland, and lies at the centre of the much larger Glasgow city-region of approximately 1.8 million people (GCC, 2018b). In common with many other cities in the United Kingdom (UK) Glasgow aspires to become a 'smart' or 'future' city (GCC, 2011). In 2012, GCC won a UK-wide 'Future cities demonstrator competition' (United Kingdom Government, 2017). The competition, which was funded in part by IBM, was organised by the Technology Strategy Board (Technology Strategy Board,
2013), now Innovate UK (a non-departmental body which is part of the UK Government). Thirty cities took part in the competition and $£ 24$ million was awarded to GCC as the overall competition winner. The concept of the proposal which GCC submitted was to undertake a single city demonstrator project known as 'Future City Glasgow' (GCC, 2018c). The demonstrator would provide evidence of benefits to the economic performance, quality of life, societal cohesion, and environmental performance (including sustainability targets) of Glasgow. The infrastructural legacy of the 2014 Glasgow Commonwealth Games was cited as a strong example of Glasgow's commitment to realise its potential as a lead- 
ing innovative municipality. The Future City Glasgow programme (FCGP) ran from February 2013 to August 2015, and a team of around twenty-six personnel was established to manage all aspects of the programme, the key components of which were:

- the creation of an integrated Operations Centre, bringing together traffic management, security, and public space CCTV;

- construction of a City Data Hub to allow for easier access to open datasets (health, socio-economic, demographic and other information);

- individual demonstrator projects to facilitate innovation in: Active Travel (cycling and walking); Social Transport; Energy Efficiency, and Intelligent Street Lighting; and,

- investment in physical infrastructure to support integration of city systems.

This case study considers the extent to which there has been transition in Glasgow towards a 'smart' or 'future' city through the FCGP and from ongoing smart legacy projects, such as the transformation programme (GCC, 2015a). The analysis provides an opportunity to assess whether or not the city of Glasgow is delivering 'smart governance' to its citizens, and if so, how is this being achieved? By smart governance, we mean the opportunities which citizens have had to become involved in local decision-making processes through engagement (Gabrys, 2014), participation (Chourabi et al., 2012), coproduction (Alford \& Yates, 2015), and, the co-creation of value (Osborne, Radnor, \& Strokosch, 2016). Importantly, we assess where these practices have occurred through the use of smart technologies, including social media. Table 1 sets out a timeline of key dates and activities in the evolution and development of Future City Glasgow.

Governance of the FCGP was provided through the FCGP Demonstrator Delivery Board and Executive Steering Group, and partnership infrastructures were established across the public, private and academic sectors (GCC, 2015b). The final evaluation report on the FCGP was submitted to GCC in 2017 (mruk, 2017), and analysis of this is provided at Section 4. Our case study findings reveal extensive use of online consultation mechanisms to solicit the views of citizens, on a wide variety of proposals affecting their neighbourhoods. These include, Facebook, Twitter and dedicated project webpages to inform citizens of current events and projects. Citizens have been encouraged to participate in discussion, for example cycling groups have been engaged to shape cycling infrastructure investment via crowdsourcing techniques and apps. Schoolchildren were involved in using 'code' to improve their ICT skills and all latter-stage primary school children in the city were provided with a tablet (Paterson, 2017). Although a range of mechanisms have been used, online participation levels appear to be relatively low and further empirical investigation is required to determine the reasons for this. It would be useful to understand more about the socio-demographic composition of participating citizens, the extent of their influence and community groups' capacity for building social capital.

The remainder of the article is split into six main sections. Section 2 sets out the methods underpinning the research presented here, with specific reference to the 'SmartGov' transnational research project. Section 3 provides more information about the literature review conducted for this research. Section 4 evaluates three of the FCGP projects (Energy Efficiency, Active Travel and Open Glasgow). Section 5 discusses the FCGP in relation to how Smart governance is being delivered. Section 6 provides some concluding comments.

\section{Methodology}

The research underpinning this case study derives from the SmartGov 'Smart Governance of Sustainable Cities' research project, 2015-2019. SmartGov is a four-year collaborative transnational multi-disciplinary project, examining the value of information and communication technologies (ICTs) for engaging citizens in the governance of sustainable cities. The project involves research teams from the Netherlands, UK and Brazil. The research methodology incorporates a 'systematic' literature review, a comparative analytical framework, semi-structured interviews, practitioner engagement (co-production) in research design, case studies and networking and capacity building as a co-production technique. The SmartGov project considered legacy outcomes of the FCGP in terms of citizen engagement in using ICTs, sustainability and governance.

In September 2016, the University of Stirling approved the ethical structure for the empirical investigation to be carried out by SmartGov research team. This included proposals to undertake semi-structured interviews with officers (employees) and elected members (councillors) of GCC, and citizens and citizens' groups within Glasgow. The interviews involving officers were agreed jointly with GCC on the basis of the officers' prior involvement with the various Demonstrator projects of the FCGP. The interviews with elected members were arranged in accordance with their allocated responsibility through appointed Convenerships and committee memberships within the council. Interviews with citizens and citizens groups were organised in relation to their known participation in either the FCGP, or its legacy projects. The SmartGov research team has assisted GCC in the coproduction of potential citizen-engagement mechanisms regarding the $\mathrm{H} 2020$ 'RUGGEDISED' innovative energy renewables project (EU, 2018), and GCC has participated in the annual virtual conferences of the SmartGov project, which has involved all three academic partners associated with the project and practitioner partners from the three respective case study cities. Several meetings have been held with officers from GCC to discuss the delivery of the different stages of the empirical work, 
Table 1. Timeline: Future City Glasgow.

\begin{tabular}{|c|c|c|}
\hline Date & Organisation & Activity \\
\hline June 2012 & $\begin{array}{l}\text { Technology Strategy } \\
\text { Board }\end{array}$ & $\begin{array}{l}\text { Report announcing 'Future cities demonstrator' competition for } \\
\text { large-scale demonstrator project funding. }\end{array}$ \\
\hline 14 November 2012 & Glasgow City Council & $\begin{array}{l}\text { Final Report to Technology Strategy Board proposing the establishment of } \\
\text { a 'Glasgow City Management System' to manage the Future City Glasgow } \\
\text { Demonstrator project. }\end{array}$ \\
\hline January 2013 & $\begin{array}{l}\text { Department for } \\
\text { Business, Innovation } \\
\text { and Skills }\end{array}$ & $\begin{array}{l}\text { UK Government Press release announcing Glasgow as the winner of the } \\
\text { Technology Strategy Board's 'Future Cities Demonstrator', with } f 24 m \text { GBP } \\
\text { to 'make Glasgow a city of the future'. }\end{array}$ \\
\hline 20 March 2013 & Glasgow City Council & $\begin{array}{l}\text { Report to Sustainability and Environment Policy Development Committee } \\
\text { confirming Glasgow's successful bid for funding of } f 24 m \text { from the } \\
\text { Technology Strategy Board (TSB) Future Cities Demonstrator competition. }\end{array}$ \\
\hline 26 November 2014 & Glasgow City Council & $\begin{array}{l}\text { Report to Sustainability and Environment Policy Development Committee } \\
\text { advising on progress with the publishing of over } 370 \text { datasets on the } \\
\text { OPEN Glasgow portal, and how these datasets might be analysed to assist } \\
\text { with service planning. }\end{array}$ \\
\hline 26 November 2014 & Glasgow City Council & $\begin{array}{l}\text { Report to Sustainability and Environment Policy Development Committee } \\
\text { providing an overview of the Future Hacks (Hackathon) events that took } \\
\text { place as a component of the Future City Glasgow Programme. }\end{array}$ \\
\hline 18 March 2015 & Glasgow City Council & $\begin{array}{l}\text { Report to Sustainability and Environment Policy Development Committee } \\
\text { with a progress update on the Future City Glasgow programme, including: } \\
\text { the creation of an integrated operations centre; construction of a City } \\
\text { Data Hub to enable easier access to open datasets, and showing the value } \\
\text { of an integrated programme of digital activity in support of Glasgow's } \\
\text { Strategic Plan 2012/17. }\end{array}$ \\
\hline July 2015 & Glasgow City Council & $\begin{array}{l}\text { Overview of project reporting within the Future City Glasgow programme, } \\
\text { summarising progress to date on the build phase of Open Glasgow and } \\
\text { each of the demonstrators (Energy Efficiency; Integrated Social Transport; } \\
\text { Intelligent Street Lighting; Active Travel) including recommendations to } \\
\text { undertake further workstreams and proceeding to Phase } 2 \\
\text { demonstrator phase. }\end{array}$ \\
\hline October 2015 & Innovate UK & $\begin{array}{l}\text { Report on the impact of the } ₫ 34.5 \mathrm{~m} \text { future city challenge, including focus } \\
\text { on Glasgow's achievements, and how cities across the UK could take } \\
\text { advantage of technology to be better places to live, work and play. }\end{array}$ \\
\hline 16 March 2016 & Glasgow City Council & $\begin{array}{l}\text { Report to Sustainability and Environment Policy Development Committee } \\
\text { on GCC's role in the ERDF programme: 'Scotland's 8th City-The } \\
\text { Smart City'. }\end{array}$ \\
\hline 2017 & mruk & $\begin{array}{l}\text { 'Building a Future City': Future City Glasgow Evaluation, prepared for } \\
\text { Glasgow City Council. }\end{array}$ \\
\hline
\end{tabular}

to ensure its practical value and the co-production of value. At the time of writing, historical research concerning the Future City Demonstrator has been completed, along with a series of detailed case studies and site visits. To date, 25 interviews have been completed. Ongoing empirical research is taking place around a number of legacy initiatives.

In relation to this article and its focus on smart governance and citizen engagement, three projects from FCGP were selected for detailed investigation: Energy Efficiency; Active Travel; and, Open Glasgow. The literature review pointed towards a potential gap in our understanding of smart governance in three overarching and connected themes, citizens and ICT engagement (Albino, Berardi, \& Dangelico, 2015), governance (Meijer \& Bolívar, 2016), and sustainability (Hara, Nagao, Hannoe, \& Nakamura, 2016). A case study analytical framework, emerging from the SmartGov project literature review, was used to analyse the three FCGP projects and is illustrated at Table 2 . This framework is used in this article to describe and assess each case in relation to the three core themes of ICT engagement, governance and sustainability-the three core components of smart governance. 
Table 2. Case study framework of analysis.

Overarching Themes

Case Study Selection

Citizens and ICTs

Governance

Sustainability

Energy Innovation

(FCGP Energy Efficiency)

Cycling and Walking

(FCGP Active Travel)

Connected Glasgow

(FCGP Open Glasgow)

\section{Literature Review}

Academic literature about the impact of Glasgow becoming a smart city is scarce and under-developed, which is perhaps understandable given how recently the FCGP concluded. Buck and While (2017, p. 502) argue that the core challenge facing policy-makers in Glasgow and elsewhere is to move the discourse from 'the attractive but elusive imaginaries to tangible intervention'. Calzada (2017) identifies a strong commitment to partnership working, although concerns are noted about the benefits of making data publicly available and the vagueness of the transformation concept. O'Connor, Gurguc and van Dam (2016) point to the 'data-centric' strategy adopted for driving improvement and the low user utility of apps such as 'MyGlasgow'. Contemporary studies of Glasgow have tended to focus on how the city is addressing the continuing challenge of emerging as a post-industrial city, for example in relation to urban regeneration (Boyle, 1990; Lever, 2017), social capital (Walsh et al., 2015), the possible existence of a detrimental 'Glasgow effect' on health (Walsh, Bendel, Jones, \& Hanlon, 2010), the geography of deprivation (Pacione, 2013), housing tenure mix (McIntyre \& McKee, 2012), the working class experience of gentrification (Paton, 2016), and sustainable transport and active travel (McCartney, Whyte, Livingston, \& Crawford, 2012). There is very little contemporary research published on the governance of smart technologies and citizen engagement in Glasgow.

The SmartGov project literature review examined over 150 academic articles, assessing what is already known about smart governance using technologically mediated citizen-centric models of engagement, such as hackathons, living labs, maker spaces, gamification, the use of 'open data', and crowdsourcing (Webster \& Leleux, 2018). Contemporary academic perspectives on smart cities/governance were reviewed in relation to urban growth and development (Albino et al., 2015), new urbanization environmental sustainability (Zygiaris, 2012), capacity-building within communities relating to quality of life and participation in society (Caragliu, Del Bo, \& Nijkamp, 2011), participation by citizens in the governance of cities (Lombardi, Giordano, Farouh, \& Yousef, 2012), and theories of social capital (Lin, 2017). Meijer and Bolivar (2016) argue that smart city governance is not a technological issue, but rather a complex process of institutional change, and that further research should focus on the critical e-Government success factors, and build upon sophisticated theories of sociotechnical change. The literature review was used to identify the elements and components of 'smart' governance, to develop analytical models, and to create frameworks to guide the project's empirical research. Allied to academic literature, 'grey' matter, in the form of reports, minutes and media publications (etc.) were collected in relation to the Future City programme and its component case study initiatives. These documents provide an important evidence base for the cases studied and are referenced throughout this article.

\section{Glasgow Future City Projects}

Two of the four core Demonstrator projects at the heart of the Glasgow Future City project and the Open Glasgow project are explored in detail in this article using the cases 'Energy Innovation' (the Energy Efficiency Demonstrator), 'Cycling and Walking' (the Active Travel Demonstrator) and 'Connected Glasgow' (the Open Glasgow project). Each is presented and discussed in relation to the three core smart governance themes of ICTs and citizens, governance and sustainability.

\subsection{Energy Innovation}

Investment in innovative new technologies and new practices to achieve reductions in demand for energy and $\mathrm{CO} 2$ emissions are sizeable challenges for the city of Glasgow, and have involved citizens, community organisations and the private/public sectors. Citizen engagement has been problematic due to the $34 \%$ of households that are estimated to be living in fuel poverty (GCC, 2016a) and which may be faced with the stark choice of whether to 'eat' or 'heat'. In 2010, GCC established 'Sustainable Glasgow' to address the challenges of climate change and set a target to reduce the city's CO2 emissions by $30 \%$ by 2020 (GCC, 2017a).

Building on the work carried out as part of the Energy Efficiency Demonstrator, GCC was successful in 2016 with a bid to undertake the 'RUGGEDISED' EU Horizon 2020 research project (EU, 2018). This project will test, 
implement and accelerate the smart city model across Europe. The 'RUGGEDISED' project, which includes the Glasgow Smart Street, has many innovative elements. These include the introduction of a roof-mounted solar PV canopy, ducted wind turbines, EV charging points, district heating proposals, and the use of stored renewable energy. GCC aims to lead the deployment of innovative technologies, helping to improve the quality of life for citizens by reducing $\mathrm{CO} 2$ emissions, improving air quality, reducing fuel poverty, improving infrastructure, and for developing opportunities to develop social capital within the city via citizen engagement.

The sub-projects which formed the FCGP Energy Efficiency Demonstrator are presented in Table 3 and included proposals for commercial and domestic properties, and the use of integrated technology/data for citizen behaviour change. Core themes which emerged from the analysis of Energy Innovation, included the active participation of citizens in energy-saving practices, and the existence of a technical competence gap which impeded the achievement of real behavioural change amongst citizens. From interviews with GCC officers, it was evident that the behavioural change tool proved to be too complex for citizens to use effectively. This meant that the intended roll-out of the tool across Glasgow was not viable. GCC also interacted with citizens via community hubs, corresponding directly to citizens and using iPads for undertaking surveys, etc. GCC analysis found

Table 3. Energy innovation.

\begin{tabular}{|c|c|}
\hline Individual Projects & Citizens and ICTs \\
\hline $\begin{array}{l}\text { 1. Virtual Building Modelling/City Energy } \\
\text { Model (development of an Energy app. } \\
\text { for enhanced understanding of energy } \\
\text { consumption). }\end{array}$ & $\begin{array}{l}\text { The energy app was to } \\
\text { be used by citizens, } \\
\text { however, it did require } \\
\text { some technical } \\
\text { knowledge which } \\
\text { limited participation. }\end{array}$ \\
\hline
\end{tabular}

Governance
Security requirements
related to personal
data, and
development of
Privacy Impact
Assessments where
identifying the data
controller/data
processor, limited the
use of data collected.
Limited opportunities
for engagement and
participation of
stakeholders in the
objectives.

Sustainability

The online virtual building tool and energy app for citizens and businesses, provide advice on actions which citizens and businesses can use to make their buildings more energy efficient.

\section{Demand-Side Management Systems} (installation of remote monitoring equipment in ten Council buildings to assist load shifting, peak shaving).

\section{Housing Tenement Retrofit}

(installation of sensors in 60 homes (of different types) to better understand the impact of retrofit-savings in energy, but potentially increased moisture levels).
This project did not involve citizens.
Limited opportunities for engagement and participation of stakeholders in the objectives.
Controlling of electrical demand will lead to reduced energy consumption and $\mathrm{CO} 2$ levels.

Citizens had no direct control over the sensors, but were consulted on the trial, and with the help of Housing Associations, most were keen to participate.

\section{Renewables-Photovoltaic (PV)}

Mapping (opportunities to host renewables such as PV on derelict sites).
The mapping exercise did not involve citizens.
Limited opportunities

for engagement and participation of stakeholders in the objectives.

\section{Behavioural Change (citizen} engagement) (Better understanding of citizens' views and concerns around energy, and development of a gamified engagement tool, specifically aimed at schoolchildren).

\begin{tabular}{|c|c|c|}
\hline $\begin{array}{l}\text { 'Gamified' engagement } \\
\text { tool developed to } \\
\text { shape behaviour of } \\
\text { Glaswegians and } \\
\text { schoolchildren to allow } \\
\text { a 'trickle-down' effect } \\
\text { amongst parents and } \\
\text { families leading to } \\
\text { reduced energy usage. }\end{array}$ & $\begin{array}{l}\text { The requirement for } \\
\text { some technical } \\
\text { knowledge to use the } \\
\text { app, and the lack of } \\
\text { 'instant' results, } \\
\text { impeded the } \\
\text { development of the } \\
\text { reach of this initiative. }\end{array}$ & $\begin{array}{l}\text { Providing accessible } \\
\text { and engaging } \\
\text { platforms to access } \\
\text { energy information, } \\
\text { may encourage } \\
\text { citizens to make } \\
\text { changes to their } \\
\text { energy consumption } \\
\text { behaviour. }\end{array}$ \\
\hline
\end{tabular}

Database was developed of building types, insulation systems, to better inform future insulation decision-making.

Improved coverage of PV renewable technologies will reduce electrical demand on the main grid system.

Providing accessible and engaging platforms to access energy information, citizens to make behaviour. 
that the 'digital divide' in some areas did not relate to technical competence. Instead, some citizens whilst being technically competent did not have an iPad, laptop, or fixed Internet connection in their home and were therefore unable to participate in the technologically mediated governance mechanisms.

\subsection{Cycling and Walking}

The promotion of active travel for citizens involving cycling and walking for transport and leisure is a Scottish Government objective (Transport Scotland, 2018). Benefits of increased levels of cycling and walking are cited as easing congestion, reducing noise pollution, cutting exhaust emissions, improving health and cost savings. In the context of the city of Glasgow, these potential benefits have particular resonance, given the city's relatively high levels of poor health and wide variations of mortality between neighbourhoods (Walsh et al., 2010). GCC has supported cycling and walking in Glasgow, through for example the 'Connecting Woodside' project which aims to deliver world class walking and cycling infrastructure (GCC, 2018d). The FCGP Active Travel Demonstrator encouraged citizens and cycling/walking groups to engage with GCC about infrastructure initiatives, through the creation of new cycling and walking apps developed alongside an education website tool. The 'Glasgow Cycling App' was launched in November 2014, cycling organisations promoted the app through their networks and actively engaged with GCC by supplying recommendations about the upgrading of routes and proposals for establishing new ones. Marketing took place through peer-to-peer networks and through social media. As of January 2016, there had been 1,200 downloads on iOS and Android and 1,393 routes had been captured with a total distance of $9,138 \mathrm{~km}$.

GCC's vision is to increase levels of cycling for leisure, sport and as a mode of transport. On 3 March 2016, the Executive Committee of GCC approved the city's Strategic Plan for cycling 2016-2025, and agreed to commit $f 2 m$ for each of the next three years on the basis that match-funding is provided by other key stakeholders. Further investment by the GCC of $£ 3 m$ was announced in June 2016 for cycling, walking and road safety projects across the city. Funding of this new investment would be supplied by five public sector partners: GCC, Strathclyde Partnership for Transport; Sustrans Scotland; Paths for All; and, Transport Scotland-Walking Safer Streets Fund (GCC, 2016b). The sub-projects of the Active Travel Demonstrator are reviewed in Table 4. Core themes which emerged from the analysis of Cycling and Walking included active citizen participation and the codesign of new cycling and walking routes, improved infrastructure which could lead to healthier lifestyles for cyclists and walkers, the creation of new apps which has led to improved conditions for knowledge transfer capabilities, and successful community/business networking.

\subsection{Connected Glasgow}

Whilst GCC claimed to have one of the most popular council Twitter feeds in the UK, with over 26,200 followers (GCC, 2011), a survey by Citizens Advice Scotland (Anderson, Gijón, \& Whalley, 2015) found clear links between age, deprivation and Internet use in Glasgow. The survey showed that $42 \%$ of residents had never used the Internet and almost half had no computer or Internet connection in their home. A core feature of Glasgow's aspiration to be a 'future city' was to increase citizenengagement through the use of innovative new technologies. This presented unique challenges for Glasgow, as in comparison to other Scottish cities, it had the greatest percentage of households living in poverty (approaching 50\%) (The Scottish Government, 2018).

The Open Glasgow project included proposals for empowering communities to allow them to engage in local affairs and decision-making, and to encourage citizens to contribute data 'rich with local knowledge'. The Open Glasgow project had a diverse range of subprojects, including Hackathon events (Future Hacks) being held on the topics of public safety, energy, and health and transport. The creation of the Glasgow Operations Centre, provided an integrated multi-public service command and control centre for monitoring Glasgow's security, traffic management and public space CCTV systems. Open datasets were published so that citizens could access service and administrative data, and the creation of a MyGlasgow Smartphone app allowed citizens to access information and provide comments to GCC. The subprojects of the Open Glasgow project are reviewed in Table 5. Core themes which emerged from the analysis of Connected Glasgow included the challenge of how to create sustainable engagement mechanisms which allow increasing levels of citizen awareness, engagement and participation, and how to improve data literacy skills, and reduce digital exclusion. Formal reporting by GCC and case study research for the SmartGov project suggests that whilst a number of data sets are now accessible there has been limited public interest in using them. This may be because of limited awareness of what data is available or because of limited data skills in how to access, process and use such data. Research also points to the Hackathon mechanism as a productive means to generate interest in using data and designing service solutions amongst small expert technical communities. The MyGlasgow app was also deemed a success and was widely used by Glaswegians for a variety of purposes, including providing feedback on local public policy initiatives.

\section{Discussion}

Unlike rapidly expanding cities in Africa, South East Asia and South America (Hoornweg \& Pope, 2017), the drive to find sustainable smart solutions to urban problems in Glasgow has not been fuelled by increasing migration 
Table 4. Cycling and walking.

\begin{tabular}{llll}
\hline Individual Projects & Citizens and ICTs & Governance & Sustainability \\
\hline 1. Mapped Current Infrastructure (for & This sub-project laid the & Encouraging citizens to & Promotion of healthier \\
active and sustainable travel using & groundwork for future & communicate with GCC & lifestyles and behaviour \\
spatial analysis). & online engagement & using online tools, & change through active \\
& with citizens. & proved to be an & travel, and improved \\
& & effective engagement & quality of life is a GCC \\
& & mechanism. & objective for Glasgow's \\
& & & citizens.
\end{tabular}

2. Development of 'Glasgow Walking App' and 'Glasgow Cycling App'.
Glasgow citizens actively participated in the co-design of new and upgraded cycling and walking routes, supplying information through online means.
The infrastructure investment decisions which GCC made were influenced by citizens supplying their views online, making this a tangible example of 'Smart governance'.

Engagement of citizens The development of took place at the development phase of the technologies involved.

The development of
the technologies used was carried out following stakeholder engagement with health organisations, universities, schools, and passenger transport bodies.

\section{Integration of Online Mapping Tools to the developed apps.}

Engagement of citizens took place at the development phase of the technologies involved.
Information generated from the apps has been used for academic and public health studies.

\section{Encouraging the} adoption of sustainable forms of active travel, has made Glasgow more pedestrian and cyclist friendly.

\section{Promotion of healthier lifestyles and behaviour change through active travel, and improved quality of life is a GCC objective for Glasgow's citizens.} Promotion of healthier
lifestyles and behaviour
change through active
travel, and improved
quality of life is a GCC
objective for Glasgow's
citizens.
Knowledge transfer
from the cycling/
walking apps could see
communities
developing their own
apps, and potentially
helping to improve
active lifestyles and
wellbeing.

Knowledge transfer
from the cycling/
walking apps could see
communities
developing their own
apps, and potentially
helping to improve
active lifestyles and
wellbeing.

\section{Administration Platform for innovative app development.}

$\begin{array}{ll}\begin{array}{ll}\text { Engagement of citizens } \\ \text { took place at the }\end{array} & \begin{array}{l}\text { The development of } \\ \text { the apps for } \\ \text { development phase of } \\ \text { the technologies }\end{array} \\ \text { involved. } & \begin{array}{l}\text { cycling/walking has } \\ \text { helped local businesses } \\ \text { create networking } \\ \text { opportunities and } \\ \text { benefited the digital } \\ \text { economy. }\end{array}\end{array}$

Engagement of citizens economy. of the rural population from the surrounding city-region into the city. Instead, there have been declining population levels within Glasgow from a peak of over 1 million inhabitants in 1950 , to approximately 615,000 today (GCC, 2018a). The focus for urban and societal change in Glasgow has been driven by its transition from a post-industrial city and dependence on shipbuilding and heavy engineering, to a 'future' high-tech city. Compared to other cities in Scotland, Glasgow has a disproportionately high number of disadvantaged communities (approaching $50 \%$ ), which presents particular engagement challenges (The Scottish Government, 2018). Glaswegian's have the lowest life expectancy in Scotland and the lowest levels of home broadband access. GCC has produced detailed neighbourhood profiles of the city, allowing GCC to make more informed decisions about the targeting of resources (GCC, 2018a).

The aim of the research presented here is to look beyond conventional eGovernment approaches, which have had a focus on the efficient delivery of services, and to look instead at how such technologies can be used to engage citizens (Meijer, 2012; Meijer \& Bolívar, 2016). If citizens are interested in what is happening in their community, then there may be a greater chance of them participating in local decision-making. New technologies and new forms of engagement offer the pos- 
Table 5. Connected Glasgow.

\begin{tabular}{|c|c|c|c|}
\hline Individual Projects & Citizens and ICTs & Governance & Sustainability \\
\hline $\begin{array}{l}\text { 1. City Data: City Data Hub (world-leading } \\
\text { scalable big data platform); City Data Hub } \\
\text { Integration; Open Data Catalogue; Open } \\
\text { Datasets Published; Community Area } \\
\text { Partnership Map; Open City Dashboard } \\
\text { (online personalised dashboard } \\
\text { presenting real time information). }\end{array}$ & $\begin{array}{l}\text { Development of the } \\
\text { 'MyGlasgow' } \\
\text { smartphone app for } \\
\text { citizens to report } \\
\text { environmental and } \\
\text { community issues. } \\
\text { Over } 400 \text { open } \\
\text { datasets published by } \\
\text { the GCC and partner } \\
\text { organisations. }\end{array}$ & $\begin{array}{l}\text { Innovative } \\
\text { technologies made } \\
\text { available with the } \\
\text { intention of informing } \\
\text { and engaging citizens, } \\
\text { creating closer } \\
\text { relationships, while } \\
\text { encouraging } \\
\text { participation in local } \\
\text { decision-making. }\end{array}$ & $\begin{array}{l}\text { Sustainability benefits } \\
\text { arising from the } \\
\text { transition from } \\
\text { paper-based to online } \\
\text { systems are still to be } \\
\text { quantified. }\end{array}$ \\
\hline $\begin{array}{l}\text { 2. City Innovation: MyGlasgow App } \\
\text { (smartphone app allowing residents to } \\
\text { report issues to the City); Hackathons; } \\
\text { Sensor Store; Open Data Publication } \\
\text { Processes. }\end{array}$ & $\begin{array}{l}\text { Four Hackathons } \\
\text { involved } 239 \text { citizens, } \\
192 \text { hours of activity, } \\
33 \text { teams, } 30 \text { mentors, } \\
22 \text { judges, and } 1030 \\
\text { tweets for } \\
\text { \#hackglasgow. The } \\
\text { number of datasets } \\
\text { presented to each } \\
\text { 'Hack' increased from } \\
18 \text { to } 143 .\end{array}$ & $\begin{array}{l}\text { GCC considered the } \\
\text { hackathons to be an } \\
\text { effective tool for } \\
\text { engaging citizens, } \\
\text { business start-ups and } \\
\text { SMEs, and for } \\
\text { stimulating innovation. }\end{array}$ & $\begin{array}{l}\text { One of the apps } \\
\text { developed from the } \\
\text { Future Hacks, 'Health } \\
\text { Walks Plus', has a } \\
\text { strong link to the Active } \\
\text { Travel Demonstrator, } \\
\text { by directing citizens to } \\
\text { nearby walks with } \\
\text { physical markers on the } \\
\text { pavements. }\end{array}$ \\
\hline $\begin{array}{l}\text { 3. City Engagement: Open Glasgow } \\
\text { Website; Engagement Hub; Infographics; } \\
\text { Case Study Videos; Day in the Life Video; } \\
\text { Future Makers; Coder Dojo; Future Maps; } \\
\text { Open Glasgow Social Media Presence; } \\
\text { City Observatory (engagement space to } \\
\text { analyse data using a range of } \\
\text { technologies) }\end{array}$ & $\begin{array}{l}\text { Numerous } \\
\text { opportunities for } \\
\text { citizens to use new } \\
\text { technologies to engage } \\
\text { with GCC. A challenge } \\
\text { is to increase levels of } \\
\text { digital literacy and } \\
\text { reduce digital } \\
\text { exclusion. }\end{array}$ & $\begin{array}{l}\text { Citizens, including } \\
\text { schoolchildren, can } \\
\text { access information and } \\
\text { contribute their views } \\
\text { through dedicated } \\
\text { project webpages, } \\
\text { Facebook, Twitter and } \\
\text { other online means. }\end{array}$ & $\begin{array}{l}\text { Better informed } \\
\text { citizens now have more } \\
\text { information available } \\
\text { about how they can } \\
\text { take part in community } \\
\text { life, and lead healthier } \\
\text { and more active } \\
\text { lifestyles. }\end{array}$ \\
\hline
\end{tabular}

sibility of creating the necessary conditions for smart governance, co-production and the co-creation of value. Elsewhere, Webster and Leleux (2018) have argued that such smart city governance opportunities are reliant on mutual reciprocity and trust. The Economic and Social Research Council (ESRC) funded integrated Multimedia City data project, co-ordinated at the University of Glasgow (Urban Big Data Centre, 2015), provides useful survey information on Glasgow citizens' attitudes and behaviours relating to civic participation, transport, education, computer and mobile phone usage, and sustainability. It finds that active citizenry is most achievable in relation to local issues, as opposed to city wide initiatives and policy.

The FCGP has been heralded as a world leader in developing smart city solutions. In a relatively short period of time, between 2013 and 2015, a range of smart city initiatives were designed, commissioned, implemented and evaluated. This has been a significant undertaking and has required support at the highest levels within GCC. Glasgow has now entered a post-Demonstrator phase with legacy systems, new practices, and more information being generated than was previously available. This has created opportunities for using data analytics for evidence-based decision-making and for the re-design and improvement of services. Many Demonstrator subprojects have now become 'mainstream' core Council activities, including the gathering of information from intelligent street lights to reduce energy costs and carbon emissions. The increased targeting of active lifestyles has been supported through cycling and walking infrastructure investment. The development of innovative energy renewable solutions is ongoing as part of the $\mathrm{H} 2020$ 'RUGGEDISED' project. There are improved opportunities for citizens and businesses to communicate and engage with GCC online, through the MyGlasgow App, the walking app and via Facebook, Twitter and online consultation platforms. GCC has taken a holistic approach to creating a Future city by concentrating on several themes in the FCGP simultaneously-improving the quality of life, economic performance, societal benefits and the environment.

The legacy of FCGP is now being used to address fuel poverty, which is increasing in the city, by improving energy efficiency in homes and creating 'space' for new research into emerging renewable technolo- 
gies. The multi-functional and multi-technology Glasgow Operations Centre is heralded as one of the best in the UK and has successfully integrated systems and practices from across a number of public service agencies. The active travel objectives are being adopted in Council regeneration projects, such as the proposal to create a pedestrian and cycle bridge over the M8 motorway, connecting the largely deprived and excluded Sighthill community to the city centre (GCC, 2016c). Traditional methods for citizens to communicate with GCC still exist, whether this is by telephone, letter, in person, or through elected members who represent the views of the local community. In 2017, the conditions for smart governance have been substantially improved through a new city charter for consultation (GCC, 2017b). Additionally, examples from the Demonstrator projects highlight there are more opportunities afforded to citizens for accessing information online and the use of apps and social media to engage, participate, co-produce and co-create with GCC. Whilst it is evident that the capacity for smart governance in Glasgow has been enhanced it is not clear how effective these mechanisms have been or the extent to which citizens have been empowered.

\section{Concluding Comments}

This case study of smart governance in the city of Glasgow involved an examination of the FCGP through an assessment of some of its key projects, using a mixedmethods research approach including document and literature review and semi-structured interviews. The contribution provides new knowledge to the academic discourse on the FCGP, its legacy outcomes, and how smart governance is being created in a city where a significant number of citizens live in deprived areas.

The FCGP project engaged citizens through a variety of mechanisms and included 'coding for kids' and the rollout of a plan to provide every latter-stage primary schoolchild in Glasgow with a tablet device to help bridge the data literacy gap (Paterson, 2017). The importance of combining socio and technological structures to achieve co-production between government and communities is central to creating a smart city with legacy outcomes. In Glasgow this has been evidenced by the implementation of new smart services and the introduction of technologically mediated governance mechanisms. This has been achieved in a relatively short space of time and has only been realised with the availability of key resources and high-level political and administrative leadership.

At the outset of this article we raised the question of whether 'smart governance' is being delivered in Glasgow through its smart city initiatives? It is important to note the continuing and positive role played by political leaders in shaping the strategic direction of the city's transformation. In 2011, under a Labour Party Administration, GCC launched a 'Fifty Year Vision for the Future: Future Glasgow 2011-61' (GCC, 2011), followed in 2012, by the bid to undertake the FCGP. In
2017, despite a change in Administration to the Scottish National Party (SNP), plans to deliver the Future City continued. Additional challenges arose due to personnel changes in the senior management of the FCGP at approximately the mid-way stage in its lifespan. These changes presented particular difficulties in delivering the project within a very tight timescale, given that GCC had committed to spending the entire project sum of GBP $\mathrm{f} 24 \mathrm{~m}$ within a twenty-four month period. It is also evident that GCC has actively encouraged citizen engagement through social media, online surveys and dedicated community and project webpages. Citizens can now contribute their views online about major policy issues, including suggestions on budget priorities, and options on how to make savings to meet future projected budget shortfalls (GCC, 2018e). Regarding youth engagement, GCC has encouraged participants to use an online tool where they can register with other users and exchange views (GCC, 2018f).

The legacy outcomes of FCGP include new ways of engaging citizens, SMEs and corporate partners, and new ways of using data analytics to inform policy and re-design services. Smart solutions are being sought to meet challenges in infrastructure, water management, bridges, city centre footfall, pollution, traffic and parking. Work is taking place with vulnerable citizens and a key challenge of how to engage and empower such citizens has become a Council priority (O'Hagan, 2018). GCC has committed to using the legacy of the FCGP to deliver a 'Transformation Programme' where digital and data are seen as key enablers. A centre of excellence has been created for using data analytics and visualisation, where data is used as an evidence-base for decisionmaking. Through these initiatives GCC are trying to bring about cultural change where service re-design and open innovation can take place. In the short-term, the future or smart city ambitions of GCC are continuing through further funding bids. The 'RUGGEDISED' H202O innovative energy renewables $E C$ research project (EU, 2018) is utilising pioneering work carried out through the FCGP Energy Efficiency demonstrator project. Other legacy outcomes from FCGP include GCC acting as a lead partner in the Scottish Cities Alliance and the submission of a successful bid to the ERDF programme to develop Scotland's 8th city-the 'Smart City'. The 8th city is a virtual city and has a focus on two key themes of 'data' and 'technology', including increasing citizen engagement through mobile technology and social media (GCC, 2016d). There are points of interest which may be drawn from a study of Glasgow as a 'future' city which might be relevant to other cities in Scotland and beyond. First, Glasgow shares close similarities with many other cities in Scotland, in terms of its socio-demographic composition, as evidenced through the Scottish Index for Multiple Deprivation (The Scottish Government, 2018). Here, lessons can be learned about how to use technologically mediated engagement practices to reach different parts of the citizenry. Second, is the existence of a 
'digital divide' in Glasgow, evident from the low levels of Internet access (Anderson et al., 2015). This divide is likely to exist in other cities and mechanisms and practices to reach excluded elements of the population can be shared with other cities. The Scottish Cities Alliance and GCC's position as lead body for developing the Smart city allows GCC the opportunity to share its experiences of developing the Future City with other public agencies. From the research conducted for this study it is apparent that the FCGP created opportunities for citizen engagement via smart city technologies. This allowed citizens to contribute to local decision-making and influence local policy and services in a number of areas. This was achieved alongside traditional participatory mechanisms and in particular, processes associated with local representative democracy. One major challenge remains, that is for policy-makers and practitioners to reach-out and attract the interest and participation of disadvantaged communities.

Although the Glasgow Future City Programme successfully piloted a number of smart city initiatives, further empirical work is required to evaluate the efficacy of the approach to 'reaching' disadvantaged communities and for realising the full potential of smart governance. To date, a series of technologically-led smart city initiatives have been integrated with existing engagement mechanisms. These have demonstrated that an evolution to smart governance is possible, but that the key ingredients of political leadership, new financial resources, technological expertise and citizen and community engagement must be evident.

\section{Acknowledgments}

The research presented derives from 'SmartGov': 'Smart Governance of Sustainable Cities', a four year collaborative transnational, multi-disciplinary research project, on the value of ICTs for engaging citizens in governance of sustainable cities (2015-2019). Funding Councils in the United Kingdom, Economic and Social Research Council [Grant number ES/N011473/1]; the Netherlands (NWO), and Brazil (FAPESP) have co-funded and supported the research. The three project partners are Utrecht University, (the Netherlands); University of Stirling (United Kingdom), and Fundação Getulio Vargas, Sao Paulo, (Brazil). SmartGov research project website: http://smartgovproject.com.

\section{Conflict of Interests}

The authors declare no conflict of interests.

\section{Research Data Policy}

The research conducted for this article complies with the principles of the Economic and Social Research Council's Research Data policy, and will be deposited in the University of Stirling's DataSTORRE repository follow- ing completion of the project. The research also complies with the Data Management Plan and Ethics approval granted by the University of Stirling, specifically related to the SmartGov research project.

\section{References}

Albino, V., Berardi, U., \& Dangelico, R. M. (2015). Smart cities: Definitions, dimensions, performance, and initiatives. Journal of Urban Technology, 22(1), 3-21.

Alford, J., \& Yates, S. (2015). Co-production of public services in Australia: The roles of government organisations and co-producers. Australian Journal of Public Administration, 75(2), 159-175.

Anderson, G., Gijón, C., \& Whalley, J. (2015). Internet access in Glasgow's deprived areas (Report 2015). Edinburgh: Citizens Advice Scotland. Retrieved from https://www.cas.org.uk/system/files/publications/ internet_access_in_glasgow_2015_final_-_aug_15. pdf

Boyle, R. (1990). Regeneration in Glasgow: Stability, collaboration and inequity. In D. Judd and M. Parkinson (Eds.), Leadership and urban regeneration. London: Sage.

Buck, N. T., \& While, A. (2017). Competitive urbanism and the limits to smart city innovation: The UK Future Cities initiative. Urban Studies, 54(2), 501-519.

Calzada, I. (2017). The techno-politics of data and smart devolution in city-regions: Comparing Glasgow, Bristol, Barcelona, and Bilbao. Systems, 5(1). https://doi.org/10.3390/systems5010018

Caragliu, A., Del Bo, C., \& Nijkamp, P. (2011). Smart cities in Europe. Journal of Urban Technology, 18(2), 65-82.

Chourabi, H., Nam, T., Walker, S., Gil-Garcia, J. R., Mellouli, S., Nahon, K., \& Scholl, H. J. (2012). Understanding smart cities: An integrative framework. In 45th Hawaii international conference on system sciences (pp. 2289-2297). Maui: IEEE.

European Union. (2018). European Union Horizon 2020 Research and Innovation Programme. RUGGEDISED Smart City Project. Retrieved from https://www. ruggedised.eu/cities/glasgow

Gabrys, J. (2014). Programming environments: Environmentality and citizen sensing in the smart city. Environment and Planning D: Society and Space, 32(1), 30-48.

Glasgow City Council. (2011). A fifty year vision for the future: Future Glasgow 2011-2061. Glasgow: Glasgow City Council. Retrieved from https://www. glasgowconsult.co.uk/UploadedFiles/GCC\%202061\% 20A4\%20Summary\%20Final\%20online.pdf

Glasgow City Council. (2015a). Transformation strategy and programme 2016-18. Glasgow: Glasgow City Council.

Glasgow City Council. (2015b). Future City GlasgowUpdate. Glasgow: Glasgow City Council. Retrieved from http://www.glasgow.gov.uk/councillorsand 
committees/viewSelectedDocument.asp?c=P62AFQ UT81UTUTDN

Glasgow City Council. (2016a). Glasgow's housing strategy-Fuel poverty (Factsheet 12/2016). Glasgow: Glasgow City Council. Retrieved from https:// www.glasgow.gov.uk/CHttpHandler.ashx?id=36653\& $\mathrm{p}=0$

Glasgow City Council. (2016b). Cycling policy and strategy. Glasgow: Glasgow City Council. Retrieved from https://www.glasgow.gov.uk/index.aspx?articleid= 20804

Glasgow City Council. (2016c). Sighthill regeneration. Neighbourhood news (Summer 2016). Glasgow: Glasgow City Council. Retrieved from https://www. glasgow.gov.uk/CHttpHandler.ashx?id=34876\& $p=0$

Glasgow City Council. (2016d). ERDF programme'Scotland's 8th city-The smart city'. Glasgow: Glasgow City Council. Retrieved from

Glasgow City Council. (2017a). City carbon emissions update. Glasgow: Glasgow City Council. Retrieved from http://www.glasgow.gov.uk/CouncillorsandCommit tees/viewSelectedDocument.asp?c=P62AFQDNT1Z3 UTT181

Glasgow City Council. (2017b). Draft city charter report. Glasgow: Glasgow City Council. Retrieved from https://www.glasgowconsult.co.uk/KMS/dmart.aspx ?strTab=PublicDMartCompleted \&PageNumber $=2 \&$ Searching $=Y \&$ PageContext $=$ PublicDMartCompleted \& PageType $=$ search\&filter_Status $=2$

Glasgow City Council. (2018a). Population. Understanding Glasgow, The Glasgow Indicators Project. Retrieved from http://www.understandingglasgow. com/indicators/population/overview

Glasgow City Council. (2018b). Glasgow city region city deal. Retrieved from http://www.glasgowcity region.co.uk

Glasgow City Council. (2018c). Future City Glasgow. Retrieved from http://futurecity.glasgow.gov.uk

Glasgow City Council. (2018d). Connecting Woodside. The new name for Glasgow's multi-million pound active travel project. Glasgow City Council. Retrieved from https://www.glasgow.gov.uk/index.aspx?art icleid $=22509$

Glasgow City Council. (2018e). Council budget: Budget consultation 2018. Glasgow City Council. Retrieved from https://www.glasgow.gov.uk/index.aspx?art icleid $=17108$

Glasgow City Council. (2018f). Youth engagement policy commission. Glasgow City Council. Retrieved from https://www.glasgow.gov.uk/index.aspx?articleid= 19468

Hara, M., Nagao, T., Hannoe, S., \& Nakamura, J. (2016). New key performance indicators for a smart sustainable city. Sustainability, 8(3), 206. https://doi.org/ $10.3390 /$ su8030206

Hoornweg, K., \& Pope, K. (2017). Population predictions for the world's largest cities in the 21st century. Environment and Urbanization, 29(1), 195-216.
Lever, W. F. (2017). Glasgow: Policy for the postindustrial city. In R. Robson (Ed.), Managing the city: The aims and impacts of urban policy. Abingdon: Routledge.

Lin, N. (2017). Building a network theory of social capital. In N. Lin, K. Cook, \& R. S. Burt (Eds.), Social capital: Theory and research. New York, NY: Routledge.

Lombardi, P., Giordano, S., Farouh, H., \& Yousef, W. (2012). Modelling the smart city performance. Innovation: The European Journal of Social Science Research, 25(2), 137-149.

McCartney, G., Whyte, B., Livingston, M., \& Crawford, F. (2012). Building a bridge, transport infrastructure and population characteristics: Explaining active travel into Glasgow. Transport Policy, 21, 119-125.

McIntyre, Z., \& McKee, K. (2012). Creating sustainable communities through tenure-mix: The responsibilisation of marginal homeowners in Scotland. GeoJournal, 77(2), 235-247.

Meijer, A. (2012). Co-production in an information age: Individual and community engagement supported by new media. Voluntas, 23(4), 1156-1172.

Meijer, A., \& Bolívar, M. P. R. (2016). Governing the smart city: A review of the literature on smart urban governance. International Review of Administrative Sciences, 82(2), 392-408.

Mruk. (2017). Building a Future City-Future City Glasgow evaluation. Glasgow: Glasgow City Council. Retrieved from http://futurecity.glasgow.gov. uk/reports/12826M_FutureCityGlasgow_Evaluation_ Final_v10.0.pdf

O'Connor, J., Gurguc, Z., \& van Dam, K. H. (2016). Delivering urban transformation through collaborative frameworks: Future cities in the UK. Academy of Management Proceedings, 2016(1). https://doi.org/ 10.5465/ambpp.2016.17369abstract

O'Hagan, J. (2018). Design with Data-GCC Data Story. Paper presented at Digital Cities 2018: Glasgow, The Lighthouse, Glasgow, UK. Retrieved from http:// futurescotevents.com/digital-cities-2018-glasgow/ agenda

Osborne, S. P., Radnor, Z., \& Strokosch, K. (2016). Coproduction and the co-creation of value in public services: A suitable case for treatment? Public Management Review, 18(5), 639-653.

Pacione, M. (2013). Urban geography: A global perspective. Abingdon: Routledge.

Paterson, S. (2017, April 17). Every pupil from P6 up in Glasgow to get a FREE tablet device. The Evening Times. Retrieved from http://www.eveningtimes. co.uk/news/15223889.Every_pupil_from_P6_up_in_ Glasgow_to_get_a_FREE_tablet_device

Paton, K. (2016). Gentrification: A working class perspective. Abingdon: Routledge.

Technology Strategy Board. (2013). Future cities demonstrator. Swindon: Technology Strategy Board. Retrieved from http://webarchive.nationalarchives. gov.uk/20130123175231/http://www.innovateuk.org 
/content/competition/future-cities-demonstrator.ashx

The Scottish Government. (2018). The Scottish Index of Multiple Deprivation, 2016. Edinburgh: The Scottish Government. Retrieved from http://www.gov. scot/Resource/0050/00504809.pdf

Transport Scotland. (2018). Active travel. Transport Scotland. Retrieved from https://www.transport.gov. scot/our-approach/active-travel

United Kingdom Government. (2017). Case study: Glasgow a world-leading smart city with support from Innovate UK. United Kingdom Government. Retrieved from https://www.gov.uk/government/casestudies/glasgow-a-world-leading-smart-city-with-sup port-from-innovate-uk

Urban Big Data Centre. (2015). iMCD project: Glasgow Household survey and Twitter data. Urban Big Data Centre. Retrieved from http://ubdc.ac.uk/data- services/data-catalogue/imcd-data

Walsh, D., McCartney, G., McCullough, S., van der Pol, M., Buchanan, D., \& Jones, R. (2015). Comparing levels of social capital in three northern post-industrial UK cities. Public Health, 129(6), 629-638.

Walsh, D., Bendel, N., Jones, R., \& Hanlon, P. (2010). Investigating a 'Glasgow effect': Why do equally deprived UK cities experience different health outcomes? (Project Report). Glasgow: Glasgow Centre for Population Health.

Webster, C. W. R., \& Leleux, C. (2018). Smart governance: Opportunities for technologically-mediated citizen co-production. Information Polity, 23(1), 95-110.

Zygiaris, S. (2012). Smart city reference model: Assisting planners to conceptualize the building of smart city innovation ecosystems. Journal of the Knowledge Economy, 4, 217-231.

\section{About the Authors}

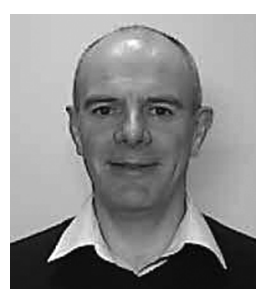

Charles Leleux is a Researcher with CRISP (the Centre for Research into Information, Surveillance and Privacy), Stirling Management School, University of Stirling, UK. He provides research support to the Economic and Social Research Council funded SmartGov research project (2015-19). SmartGov is investigating the smart governance of sustainable cities, involving citizens participating in local affairs using new ICTs. He has worked on several European Commission funded research projects involving surveillance in society.

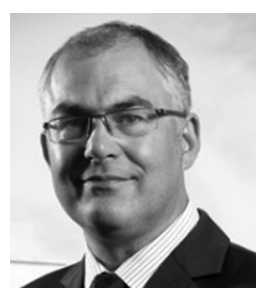

William Webster is Professor of Public Policy and Management at Stirling Management School, University of Stirling, UK. He is a Director of CRISP (the Centre for Research into Information Surveillance and Privacy), a research centre dedicated to understanding the social impacts and consequences of technologically mediated surveillance practices. Professor Webster has research expertise in the policy processes, regulation and governance of CCTV, surveillance in everyday life, privacy and surveillance ethics, as well as public policy relating to data protection, e-government, and electronic public services. He is Editor-in-Chief of the journal Information Polity. 